\title{
Factors affecting the polyunsaturated fatty acid content of the plasma lipids of sheep
}

\author{
By J. H. MOORE, R. C. NOBLE and W. STEELE \\ Hannah Dairy Research Institute, Ayr \\ (Received 22, February 1968-Accepted 6 May 1968
}

\begin{abstract}
I. In Expt I, four adult wether sheep were given diets of hay or dried grass in an alternating sequence of feeding treatments. Each treatment period lasted for 20 days and blood samples were taken from the sheep on the last day of each period. When the diet of hay (linoleic: linolenic acid ratio ${ }^{4} \cdot 40$ ) was replaced by one of dried grass (linoleic:linolenic acid ratio 0.28 ), there was an increase in the concentration of linolenic acid and a decrease in the concentration of linoleic acid in the plasma cholesteryl esters and phospholipids. There was an increase in the concentration of stearic acid and a decrease in the concentration of palmitic acid in the plasma triglycerides. Dietary change did not affect the composition of the plasma unesterified fatty acids.

2. In Expt 2, two adult wether sheep, each with a rumen fistula, were given daily intraruminal infusions of $60 \mathrm{~g}$ of 'linolenic' or 'linoleic' acids (both about $70 \%$ pure) over a period of 5 days. The infusion treatments were then reversed. Blood samples were taken at the end of each infusion period. Intraruminal infusions of 'linolenic' acid increased the concentration of linolenic acid in the plasma cholesteryl esters and phospholipids and increased the concentration of stearic acid in the plasma triglycerides. The infusions of 'linoleic' acid increased the concentration of linoleic acid in the plasma cholesteryl esters and phospholipids. No appreciable changes were observed in the composition of the plasma unesterified fatty acids.
\end{abstract}

In preliminary studies on the metabolism of lipids by ruminants, we noted (Moore, Noble \& Steele, unpublished) that the linoleic:linolenic acid ratio in the plasma lipids of sheep given a diet of hay was consistently higher than the corresponding ratio in the plasma lipids of other sheep given a diet of dried grass. It is known that the linoleic:linolenic acid ratio in hay is greater than the ratio of these two $\mathrm{C}_{18}$ polyunsaturated fatty acids in dried grass (J. W. Czerkawski, unpublished observations). Thus, in spite of the extensive hydrogenation of polyunsaturated fatty acids that is known to take place in the rumen (cf. Shorland, Weenink, Johns \& McDonald, 1957), it appeared that the composition of the dietary polyunsaturated fatty acids might be exerting some influence on the polyunsaturated fatty acid composition of the plasma lipids of the sheep. However, these preliminary observations were made on sheep of different breeds and ages, so it was decided to carry out a more detailed investigation of the effects of hay and dried grass on the composition of the polyunsaturated fatty acids circulating in the plasma of sheep. In addition, an investigation was made of the effects of intraruminal infusions of different polyunsaturated fatty acids on the fatty acid composition of the various lipid fractions in the plasma. The results of these investigations are now reported.

\section{EXPERIMENTAL}

\section{Animals, diets and procedure}

Expt I. Four adult wether sheep (mean weight $66 \mathrm{~kg}$ ) were housed in individual metabolism cages. Two of the sheep were of the Hampshire breed and two were of the Cheviot breed. During the experiment, the sheep were given either $900 \mathrm{~g}$ hay or 
$900 \mathrm{~g}$ dried grass per day in two equal portions at 07.00 and $17.00 \mathrm{~h}$, the morning and afternoon feeds respectively. The sheep were given water ad lib. Each sheep was randomly assigned to one treatment sequence of a $4 \times 4$ Latin square that was balanced for carry-over effects. However, since there were only two dietary treatments (hay or dried grass), each animal was assigned to the same dietary treatment twice during the experiment. The experiment lasted for 80 days and each treatment period lasted for 20 days. With a few drops of a solution of trisodium citrate dihydrate $(3.8 \%, \mathrm{w} / \mathrm{v})$ as an anticoagulant, blood samples were taken from the jugular veins of the animals at $\mathrm{I} 0.00$ and $\mathrm{I} 5.00 \mathrm{~h}$ on the $\mathrm{I} 9 \mathrm{th}$ and 20 th days of each treatment period.

Expt 2. Two adult wether sheep of the Hampshire breed (mean weight $64 \mathrm{~kg}$ ), each with a permanent rumen fistula, were housed in individual metabolism cages. Throughout the experiment, the animals were given water $a d l i b$. and $900 \mathrm{~g}$ hay per day in two equal portions at 07.00 and $\mathrm{I} 7.00 \mathrm{~h}$. On days $\mathrm{I}-5$ of the experiment one sheep (no. 5) was given a daily intraruminal infusion of $60 \mathrm{~g}$ 'linolenic' acid and the other sheep (no. 6) was given a daily intraruminal infusion of $60 \mathrm{~g}$ 'linoleic' acid. During days 6-10 of the experiment the infusion treatments were reversed, i.e. sheep no. 5 was given a daily intraruminal infusion of $6 \circ \mathrm{g}$ 'linoleic' acid and sheep no. 6 was given a daily intraruminal infusion of $6 \circ \mathrm{g}$ 'linolenic' acid. On the day before the sheep were given the infusions of fatty acids and on the $5^{\text {th }}$ and roth days of the experiment, blood samples were taken from the jugular veins of the sheep at 10.00 and $15.00 \mathrm{~h}$ as in Expt $\mathrm{I}$.

The 'linolenic' and 'linoleic' acids were both about $70 \%$ pure (Table $\mathrm{r}$ ) and were gifts from Price's (Bromborough) Ltd, Bebington, Cheshire. The fatty acids were administered to the animals in the form of emulsions prepared by homogenizing $60 \mathrm{~g}$ of fatty acid in $200 \mathrm{ml}$ of $0 . \mathrm{I} \%(\mathrm{w} / \mathrm{v})$ Tween 80 (polyoxyethylene sorbitan monooleate, obtained from Honeywill and Stein Ltd, London). The emulsions were infused at constant rate ( $100 \mathrm{ml}$ emulsion/h) into the rumen with a metering pump (Distillers Company Ltd, Epsom, Surrey). The daily dose of fatty acids was given to the sheep in two equal portions, each of $100 \mathrm{ml}$ emulsion containing $30 \mathrm{~g}$ fatty acid. One portion was infused into the rumen while the sheep was eating the morning feed and the other while it was eating the afternoon feed.

\section{Extraction of lipids and methods of analysis}

The total fatty acid contents of the hay and dried grass were determined as described by Moore \& Williams (1963). The lipids were extracted from the samples of plasma by the method of Nelson \& Freeman (1959). The lipid extracts of the plasma derived from the morning and afternoon blood samples obtained from each sheep were pooled before analysis and their total lipid contents were determined gravimetrically. The composition of the fatty acids extracted from the hay and dried grass and the fatty acid compositions of the plasma lipid fractions (cholesteryl esters, triglycerides, unesterified fatty acids and phospholipids) were determined by methods described in detail by Moore \& Williams (1964) and Noble \& Moore (1964) except that the gasliquid chromatography was carried out with an instrument fitted with dual flame ionization detectors (Perkin-Elmer Ltd, Beaconsfield, Bucks.). 


\section{RESULTS}

Expt I. The total fatty acid contents (g/100 g dried material) of the hay and dried grass were 0.64 and $\mathrm{I} \cdot 4$ respectively. The linoleic: linolenic acid ratios in the hay and dried grass were $I \cdot 40$ and $0 \cdot 28$ respectively (Table $I$ ). The concentrations of total lipid in the samples of plasma were unaffected by the dietary treatments and the results are therefore not given in detail. The mean value obtained for the four sheep

Table I. Major fatty acids (weight percentages of the total) present in the hay and dried grass and in the samples of 'linolenic' and 'linoleic' acids (about 70\% pure) used in the infusion experiments

$\begin{array}{lrccc}\begin{array}{l}\text { Fatty } \\ \text { acid" }\end{array} & \text { Hay } & \begin{array}{c}\text { Dried } \\ \text { grass }\end{array} & \begin{array}{c}\text { 'Linolenic' } \\ \text { acid }\end{array} & \begin{array}{c}\text { 'Linoleic' } \\ \text { acid }\end{array} \\ \text { I6:0 } & 20.7 & 14.7 & - & 15.2 \\ 16: 1 & 2.2 & 0.8 & - & 0.3 \\ 18: 0 & 5.6 & 2.1 & - & 2.2 \\ 18: 1 & 18.9 & 4.2 & 8.4 & 10.9 \\ 18: 2 & 25.0 & 16.0 & 21 \cdot 6 & 71 \cdot 1 \\ 18: 3 & 17.9 & 56.6 & 70.0 & -\end{array}$

* Shorthand designation of Farquhar, Insull, Rosen, Stoffel \& Ahrens (1959).

Table 2. Expt $\mathrm{I}$ : fatty acid compositions (major components, weight percentage of the total) of the plasma lipid fractions of sheep given diets of hay or dried grass

(Mean values with their standard errors)

\begin{tabular}{|c|c|c|c|c|c|c|c|c|c|c|c|c|}
\hline \multirow[b]{2}{*}{$\begin{array}{l}\text { Fatty } \\
\text { acid* }\end{array}$} & \multicolumn{3}{|c|}{ Cholesteryl esters } & \multicolumn{3}{|c|}{ Triglycerides } & \multicolumn{3}{|c|}{$\begin{array}{l}\text { Unesterified } \\
\text { fatty acids }\end{array}$} & \multicolumn{3}{|c|}{ Phospholipids } \\
\hline & $\begin{array}{l}\text { Hay } \\
\text { diet }\end{array}$ & $\begin{array}{c}\text { Dried- } \\
\text { grass } \\
\text { diet }\end{array}$ & SEM & $\begin{array}{l}\text { Hay } \\
\text { diet }\end{array}$ & $\begin{array}{c}\text { Dried- } \\
\text { grass } \\
\text { diet }\end{array}$ & SEM & $\begin{array}{l}\text { Hay } \\
\text { diet }\end{array}$ & $\begin{array}{l}\text { Dried- } \\
\text { grass } \\
\text { diet }\end{array}$ & SEM & $\begin{array}{l}\text { Hay } \\
\text { diet }\end{array}$ & $\begin{array}{c}\text { Dried- } \\
\text { grass } \\
\text { diet }\end{array}$ & SEM \\
\hline 16:0 & 14.3 & $13 \cdot 6$ & \pm 0.58 & $32 \cdot 8$ & $28 \cdot 4^{* * *}$ & $\pm I \cdot 22$ & $25 \cdot 6$ & $26 \cdot 2$ & $\pm I \cdot I 3$ & $20 \cdot 2$ & $17 \cdot 9 * *$ & \pm 0.53 \\
\hline 16:1 & $2 \cdot 8$ & $2 \cdot 8$ & \pm 0.27 & $4^{\cdot I}$ & $4 \div 3$ & \pm 0.62 & $3 \cdot 5$ & 377 & \pm 0.44 & $\mathbf{I} \cdot \mathbf{2}$ & $1 \cdot 3$ & \pm 0.18 \\
\hline I8:0 & 3.5 & $4 \cdot I$ & \pm 0.31 & $26 \cdot 9$ & $37 \cdot 3 * * *$ & $\pm I \cdot 38$ & $33 \cdot 2$ & $33 \cdot 9$ & $\pm I \cdot 33$ & $25 \cdot 5$ & $28 \cdot 3 * *$ & \pm 0.71 \\
\hline I8: 1 & $35 \cdot 3$ & $33 \cdot 8$ & \pm 0.59 & $28 \cdot 5$ & $24 \cdot 5$ & $\pm I \cdot 36$ & $32 \cdot 4$ & $3 I \cdot 0$ & $\pm I \cdot x_{5}$ & $20 \cdot 3$ & 20.4 & \pm 0.62 \\
\hline $18: 2$ & $33 \cdot 3$ & $28 \cdot I * *$ & $\pm I \cdot 30$ & $5 \cdot 3$ & $3 \cdot 2$ & \pm 0.68 & $2 \cdot 7$ & $2 \cdot 6$ & \pm 0.38 & I $5 \cdot 8$ & $13 \cdot 2 * *$ & \pm 0.54 \\
\hline $18: 3$ & $5 \cdot 1$ & $10 \cdot 2 * * *$ & \pm 0.72 & Trace & Trace & - & Trace & Trace & - & $2 \cdot 5$ & $5 \cdot 4 * * *$ & \pm 0.45 \\
\hline $20: 4$ & $2 \cdot 8$ & $2 \cdot 8$ & \pm 0.14 & - & - & 一 & 一 & - & 一 & $7 \cdot 5$ & $7 \cdot I$ & \pm 0.66 \\
\hline $\left.\begin{array}{l}22: 5 \\
22: 6\end{array}\right\}$ & - & 一 & - & - & 一 & - & - & - & - & 4.7 & $4^{\cdot I}$ & \pm 0.32 \\
\hline
\end{tabular}

* Shorthand designation of Farquhar et al. (1959).

**, *** Significantly different $(P<0.01, P<0.001)$ from the values obtained from the sheep on the hay diet.

during the experiment was $196 \mathrm{mg}$ total lipid/100 $\mathrm{ml}$ plasma. Qualitative thin-layer chromatography of the plasma lipid extracts on silica gel G (E. Merck, A.G., Darmstadt, Germany) with a solvent system of hexane-diethyl ether-formic acid (80:20:1, $\mathrm{v} / \mathrm{v} / \mathrm{v}$ ) indicated that the composition of the lipids in the plasma of the sheep was unaltered by the dietary treatment. Therefore, quantitative analyses of the various plasma lipid fractions were not carried out. However, it was quite clear from visual 
examination of the thin-layer chromatograms that cholesteryl esters constituted the major fraction of the plasma lipids of the sheep. Phospholipids accounted for a smaller but, nevertheless, substantial proportion of the plasma lipids, but triglycerides and unesterified fatty acids were relatively minor components.

The fatty acid compositions of the lipid fractions in the plasma of the sheep on the two dietary treatments are given in Table 2, from which it may be seen that only the plasma cholesteryl esters and phospholipids contained polyunsaturated fatty acids in appreciable concentrations. The plasma triglycerides and unesterified fatty acids contained low concentrations of linoleic acid but only trace concentrations of linolenic and arachidonic acids. When the diet of hay was replaced by one of dried grass, there was an increase in the concentration of linolenic acid and a decrease in the concentration of linoleic acid in the plasma cholesteryl esters. Similar changes in the concentrations of these two $\mathrm{C}_{18}$ polyunsaturated fatty acids occurred in the plasma phospholipids when the sheep were given dried grass instead of hay. It is of interest to note that when the sheep were given the hay diet, the linoleic:linolenic acid ratios in the plasma cholesteryl esters and phospholipids were 6.5 and 6.3 respectively; when the sheep were given the diet of dried grass these ratios were $2 \cdot 7$ and $2 \cdot 4$ respectively. The dietary change did not affect the composition of the unesterified fatty acids in the plasma. The change from the hay to the dried-grass diet resulted in a marked increase in the concentration of stearic acid and a decrease in the concentration of palmitic acid in the plasma triglycerides. Similar but smaller changes in the concentration of stearic and palmitic acids were observed in the plasma phospholipids.

Expt 2. Preliminary results indicated that intraruminal infusions of 'linolenic' or 'linoleic' acids did not appear to affect either the concentration of total lipid in the plasma of the sheep or the proportions of cholesteryl esters, triglycerides, unesterified fatty acids and phospholipids in the total plasma lipids. Detailed analyses were, therefore, not carried out. The fatty acid compositions of the plasma cholesteryl esters of sheep nos. 5 and 6 before and after intraruminal infusions of 'linolenic' or 'linoleic' acids are given in Table 3 . With sheep no. 5 , the infusions of 'linolenic' acid (days I-5) resulted in a twofold increase in the concentration of linolenic acid in the plasma cholesteryl esters. This increase occurred mainly at the expense of oleic acid, the concentration of which decreased from $40 \%$ to $31 \%$. There was no decrease in the concentration of linoleic acid, but it must be remembered that the 'linolenic' acid infused into the rumen contained $22 \%$ linoleic acid (Table $\mathrm{I}$ ). The subsequent intraruminal infusions of 'linoleic' acid (days 6-ro) markedly increased the concentration of linoleic acid and decreased the concentration of linolenic acid in the plasma cholesteryl esters. With sheep no. 6 , the infusion of 'linoleic' acid (days I-5) resulted in a pronounced increase in the concentration of linoleic acid and a pronounced decrease in the concentration of oleic acid in the plasma cholesteryl esters; the concentration of linolenic acid did not change. A twofold increase in the concentration of linolenic acid occurred in the plasma cholesteryl esters after the infusions of 'linolenic' acid (days 6-ro). This increase occurred mainly at the expense of linoleic acid, the concentration of which decreased from $48 \%$ to $38 \%$.

The fatty acid compositions of the plasma triglycerides of sheep nos. 5 and 6 before 
and after intraruminal infusions of 'linolenic' and 'linoleic' acids are given in Table 4. With sheep no. 5 the infusion of 'linolenic' acid (days $\mathrm{I}_{-5}$ ) increased the concentrations of stearic and oleic acids but decreased the concentration of palmitic acid in the plasma triglycerides. When 'linoleic' acid was infused into the rumen of sheep no. 5 (days 6-10) the fatty acid composition of the plasma triglycerides tended to revert to that observed in the plasma triglycerides before any infusions were given. The results

Table 3. Expt 2: fatty acid compositions (major components, weight percentages of the total) of the plasma cholesteryl esters of sheep given intraruminal infusions of 'linolenic' or 'linoleic' acids (about 70\% pure)

\begin{tabular}{|c|c|c|c|c|c|c|}
\hline \multirow[b]{3}{*}{$\begin{array}{l}\text { Fatty } \\
\text { acid* }\end{array}$} & \multicolumn{3}{|c|}{ Sheep no. 5} & \multicolumn{3}{|c|}{ Sheep no. 6} \\
\hline & \multirow[b]{2}{*}{$\begin{array}{l}\text { Before } \\
\text { infusion }\end{array}$} & \multicolumn{2}{|c|}{ After infusion of } & \multirow[b]{2}{*}{$\begin{array}{l}\text { Before } \\
\text { infusion }\end{array}$} & \multicolumn{2}{|c|}{ After infusion of } \\
\hline & & $\begin{array}{l}\text { 'Linolenic' } \\
\text { acid (day 5) }\end{array}$ & $\begin{array}{c}\text { 'Linoleic' } \\
\text { acid (day ıo) }\end{array}$ & & $\begin{array}{l}\text { 'Linoleic' } \\
\text { acid (day 5) }\end{array}$ & $\begin{array}{l}\text { 'Linolenic' } \\
\text { acid (day ro) }\end{array}$ \\
\hline 16:0 & $15^{\circ} 0$ & $17 \cdot 7$ & I3.3 & 15.6 & I3.5 & 14.4 \\
\hline I6:I & $2 \cdot I$ & $\mathbf{I} \cdot 6$ & $2 \cdot 1$ & $2 \cdot 2$ & $\mathrm{I} \cdot 8$ & $2 \cdot 3$ \\
\hline I 8:0 & $4 \cdot 9$ & $5 \cdot 3$ & 3.9 & $4 \cdot 3$ & $3 \cdot 4$ & $3 \cdot 4$ \\
\hline I $8:$ I & 39.5 & $3 I \cdot 3$ & $27 \cdot 7$ & $33 \cdot 8$ & $23 \cdot 8$ & $26 \cdot 4$ \\
\hline $18: 2$ & $27 \cdot 5$ & $29 \cdot 8$ & $42 \cdot 7$ & $32 \cdot 6$ & $47 \cdot 6$ & $3^{8 \cdot 1}$ \\
\hline I $8: 3$ & $3 \cdot 6$ & $7 \cdot 3$ & $2 \cdot 9$ & $3 \cdot 3$ & $3 \cdot 4$ & $7 \cdot 3$ \\
\hline $20: 4$ & $2 \cdot 3$ & $2 \cdot 0$ & $2 \cdot 2$ & $3 \cdot 2$ & $2 \cdot 0$ & $3 \cdot 1$ \\
\hline
\end{tabular}

Table 4. Expt 2: fatty acid compositions (major components, weight percentages of the total) of the plasma triglycerides of sheep given intraruminal infusions of 'linolenic' or 'linoleic' acids (about 70\% pure)

\begin{tabular}{|c|c|c|c|c|c|c|}
\hline \multirow[b]{3}{*}{$\begin{array}{l}\text { Fatty } \\
\text { acid* }\end{array}$} & \multicolumn{3}{|c|}{ Sheep no. 5} & \multicolumn{3}{|c|}{ Sheep no. 6} \\
\hline & \multirow[b]{2}{*}{$\begin{array}{l}\text { Before } \\
\text { infusion }\end{array}$} & \multicolumn{2}{|c|}{ After infusion of } & \multirow[b]{2}{*}{$\begin{array}{l}\text { Before } \\
\text { infusion }\end{array}$} & \multicolumn{2}{|c|}{ After infusion of } \\
\hline & & $\begin{array}{l}\text { 'Linolenic' } \\
\text { acid (day } 5 \text { ) }\end{array}$ & $\begin{array}{l}\text { 'Linoleic' } \\
\text { acid (day 1o) }\end{array}$ & & $\begin{array}{l}\text { 'Linoleic' } \\
\text { acid (day } 5 \text { ) }\end{array}$ & $\begin{array}{l}\text { 'Linolenic' } \\
\text { acid (day Io) }\end{array}$ \\
\hline $16: 0$ & $27 \cdot 9$ & $19 \cdot 9$ & $25 \cdot 3$ & $34 \cdot 3$ & $32 \cdot 6$ & $2 I \cdot 5$ \\
\hline $16: I$ & $5 \cdot 5$ & 2.5 & $2 \cdot 6$ & $6 \cdot 1$ & $2 \cdot 3$ & $4 \cdot I$ \\
\hline I 8:0 & $22 \cdot 3$ & $27 \cdot \mathrm{I}$ & 25.9 & 20.8 & 20.8 & $28 \cdot 7$ \\
\hline $18: 1$ & $34^{\circ} 9$ & $40 \cdot 2$ & $3^{6 \cdot 7}$ & 31.0 & $33 \cdot 8$ & $34 \cdot 3$ \\
\hline $18: 2$ & 4.8 & $6 \cdot 0$ & $4 \cdot 4$ & $3 \cdot 2$ & $5 \cdot 6$ & $6 \cdot 4$ \\
\hline
\end{tabular}

for sheep no. 6 were similar in that the intraruminal infusion of 'linoleic' acid (days I-5) resulted only in small changes in fatty acid composition of the plasma triglycerides. Compared with the composition of the plasma triglycerides before any infusions were given, the infusion of 'linolenic' acid (days 6-10) into the rumen of this sheep resulted in an increase in the concentration of stearic and oleic acids and a decrease in the concentrations of palmitic acid in the plasma triglycerides. The concentrations of linoleic acid in the plasma triglycerides of sheep nos. 5 and 6 remained low and the small variations with experimental treatments were not always 
as might have been expected. For instance, the concentration of linoleic acid in the plasma triglycerides appeared to be higher when the sheep were given infusions of 'linolenic' acid than when they were given infusions of 'linoleic' acid. Linolenic acid was not detected in more than trace concentrations in the plasma triglycerides of either sheep on any of the experimental treatments.

Table 5. Expt 2: fatty acid compositions (major components, weight percentages of the total) of the plasma unesterified fatty acids of sheep given intraruminal infusions of 'linolenic' or 'linoleic' acids (about 70\% pure)

\begin{tabular}{|c|c|c|c|c|c|c|}
\hline \multirow[b]{3}{*}{$\begin{array}{l}\text { Fatty } \\
\text { acid* }\end{array}$} & \multicolumn{3}{|c|}{ Sheep no. 5} & \multicolumn{3}{|c|}{ Sheep no. 6} \\
\hline & \multirow[b]{2}{*}{$\begin{array}{l}\text { Before } \\
\text { infusion }\end{array}$} & \multicolumn{2}{|c|}{ After infusion of } & \multirow[b]{2}{*}{$\begin{array}{l}\text { Before } \\
\text { infusion }\end{array}$} & \multicolumn{2}{|c|}{ After infusion of } \\
\hline & & $\begin{array}{l}\text { 'Linolenic' } \\
\text { acid (day 5) }\end{array}$ & $\begin{array}{c}\text { 'Linoleic' } \\
\text { acid (day Io) }\end{array}$ & & $\begin{array}{l}\text { 'Linoleic' } \\
\text { acid (day } 5 \text { ) }\end{array}$ & $\begin{array}{l}\text { 'Linolenic' } \\
\text { acid (day Io) }\end{array}$ \\
\hline $16: 0$ & $23 \cdot 8$ & $23 \cdot 3$ & $22 \cdot 9$ & $25 \cdot 1$ & $26 \cdot I$ & $22 \cdot 0$ \\
\hline I6: I & $2 \cdot 9$ & $5^{\circ} 0$ & $3 \cdot I$ & $3 \cdot I$ & $2 \cdot 5$ & $4 \cdot 4$ \\
\hline 18:0 & $27 \cdot 8$ & $26 \cdot 6$ & $33 \cdot 1$ & $29 \cdot 3$ & $30 \cdot 4$ & $3 I \cdot 6$ \\
\hline I $8: 1$ & $39 \cdot 3$ & $35 \cdot 8$ & $34 \cdot 6$ & 35.4 & $33 \cdot 2$ & $33 \cdot 9$ \\
\hline I $8: 2$ & $4 \cdot 9$ & $6 \cdot 5$ & 5.0 & $6 \cdot I$ & $6 \cdot 1$ & 6.4 \\
\hline
\end{tabular}

Table 6. Expt 2: fatty acid compositions (major components, weight percentages of the total) of the plasma phospholipids of sheep given intraruminal infusions of 'linolenic' or 'linoleic' acids (about $70 \%$ pure)

\begin{tabular}{|c|c|c|c|c|c|c|}
\hline \multirow[b]{3}{*}{$\begin{array}{l}\text { Fatty } \\
\text { acid* }\end{array}$} & \multicolumn{3}{|c|}{ Sheep no. 5} & \multicolumn{3}{|c|}{ Sheep no. 6} \\
\hline & \multicolumn{3}{|c|}{ After infusion of } & \multicolumn{3}{|c|}{ After infusion of } \\
\hline & $\begin{array}{l}\text { Before } \\
\text { infusion }\end{array}$ & $\begin{array}{l}\text { 'Linolenic' } \\
\text { acid (day 5) }\end{array}$ & $\begin{array}{l}\text { 'Linoleic' } \\
\text { acid (day ro) }\end{array}$ & $\begin{array}{l}\text { Before } \\
\text { infusion }\end{array}$ & $\begin{array}{l}\text { 'Linoleic' } \\
\text { acid (day 5) }\end{array}$ & $\begin{array}{l}\text { 'Linolenic' } \\
\text { acid (day Io) }\end{array}$ \\
\hline I6:0 & r9.0 & $14 \cdot 6$ & $13 \cdot 6$ & I $8 \cdot 8$ & I 5.4 & 13.5 \\
\hline I6: I & 0.8 & 0.7 & 0.9 & 0.7 & 0.8 & $I \cdot I$ \\
\hline 18:0 & $26 \cdot 0$ & $24 \cdot 4$ & $25 \cdot 1$ & $29 \cdot 2$ & $22 \cdot 9$ & $28 \cdot 9$ \\
\hline I $8: \mathrm{I}$ & 20.5 & $20 \cdot 5$ & I 7.8 & 20.0 & $17 \cdot 3$ & $17 \cdot 3$ \\
\hline $18: 2$ & 15.8 & $18 \cdot 2$ & $26 \cdot 1$ & $15 \cdot 4$ & $30-8$ & $18 \cdot 1$ \\
\hline I $8: 3$ & $2 \cdot 6$ & $6 \cdot 4$ & $I \cdot 6$ & $1 \cdot 7$ & 0.8 & $6 \cdot 0$ \\
\hline $20: 4$ & $7 \cdot 2$ & $7 \cdot 5$ & $6 \cdot 1$ & $6 \cdot 3$ & $5 \cdot 6$ & $7 \cdot 2$ \\
\hline $\left.\begin{array}{l}22: 5 \\
22 \cdot 6\end{array}\right\}$ & $3 \cdot I$ & $3 \cdot 1$ & $3 \cdot 9$ & $3 \cdot 2$ & $2 \cdot 8$ & $2 \cdot 6$ \\
\hline
\end{tabular}

The intraruminal infusions of 'linolenic' or 'linoleic' acids did not result in any appreciable changes in the fatty acid composition of the unesterified fatty acid fraction in the plasma of the sheep (Table 5).

The fatty acid compositions of the plasma phospholipids of sheep nos. 5 and 6 before and after infusions of 'linolenic' or 'linoleic' acids are given in Table 6. With sheep no. 5 the intraruminal infusion of 'linolenic' acid (days $1-5$ ) decreased the concentration of palmitic acid and increased the concentration of linolenic acid in the plasma phospholipids; there was a small increase in the concentration of linoleic acid. 
Subsequent infusions of 'linoleic' acid (days 6-10) resulted in a marked increase in the concentration of linoleic acid in the plasma phospholipids. This increase in the concentration of linoleic acid was counterbalanced mainly by decreases in the concentrations of oleic and linolenic acids. The infusion of 'linoleic' acid (days I-5) into the rumen of sheep no. 6 resulted in a twofold increase in the concentration of linoleic acid and decreases in the concentrations of stearic and oleic acids in the plasma phospholipids. The subsequent infusion of 'linolenic' acid (days 6-10) increased the concentrations of stearic and linolenic acids, but reduced the concentration of linoleic acid in the plasma phospholipids. There were no consistent differences in the concentrations of the $\mathrm{C}_{20}$ and $\mathrm{C}_{22}$ polyunsaturated fatty acids in the plasma phopholipids of the sheep on the different experimental treatments.

\section{I CUSSION}

Garton \& Duncan (1964) reported that the percentage composition of the plasma lipids of sheep (Cheviot wethers, 6 months of age) was as follows: cholesteryl esters, 47; cholesterol, 8; triglycerides, II; unesterified fatty acids, 4; phospholipids, 28. Although the percentage compositions of the plasma lipids of the sheep were not determined in the experiments now reported, the plasma lipids of similar sheep have been analysed in our laboratory and the mean percentage composition was found to be: cholesteryl esters, 44; cholesterol, II ; triglycerides, 5; unesterified fatty acids, 5; phospholipids, 35. These results are in fair agreement with those of Garton \& Duncan (1964) and it is clear therefore that cholesteryl esters and phospholipids together account for $75-80 \%$ of the plasma lipids of sheep. The fatty acid compositions of the various plasma lipids (Tables 2-6) were similar to those reported by Garton \& Duncan (1964). Compared with our results, Garton \& Duncan (1964) found somewhat lower concentrations of palmitic acid and somewhat higher concentrations of oleic acid in all the plasma lipid fractions, and these differences could well be due to differences in diet, breed or age of the sheep. Since the plasma cholesteryl esters and phospholipids of sheep contain relatively high concentrations of linoleic acid and appreciable concentrations of linolenic acid and the $\mathrm{C}_{20}$ and $\mathrm{C}_{22}$ polyunsaturated fatty acids, it is evident that polyunsaturated fatty acids constitute a considerable proportion of the total fatty acids circulating in the blood of sheep. It is also evident that the composition of the plasma polyunsaturated fatty acids is influenced by the polyunsaturated fatty acid composition of the diet (Expt I) or by the infusion of large amounts of different polyunsaturated fatty acids into the rumen (Expt 2). The question now arises as to how the sheep is able to maintain these relatively high concentrations of plasma polyunsaturated fatty acids, the composition of which depends to some extent on the composition of the polyunsaturated fatty acids in the diet, if hydrogenation of polyunsaturated fatty acids by the rumen microflora is as efficient and complete as certain authorities (e.g. Tove \& Mochrie, 1963) have maintained. It is possible that a certain proportion of dietary polyunsaturated fatty acids escapes hydrogenation in the rumen and passes on to be absorbed from the small intestine. However, in experiments (unpublished) on sheep with abomasal fistulas we have 
been unable to detect more than trace amounts of linolenic or linoleic acids in the contents removed from the abomasum at various times after the sheep had been given meals of hay or dried grass. Nevertheless, if some dietary polyunsaturated fatty acids were absorbed from the small intestine of the sheep and if the absorption mechanism is the same as that in monogastric animals (Senior, 1964 ), then it is perhaps surprising that, when the linoleic:linolenic acid ratio in the diet was altered, changes in the linoleic:linolenic acid ratios were not observed to a greater extent in the plasma triglycerides. It is, of course, possible that more striking changes in the polyunsaturated fatty acid concentrations in the plasma triglycerides might have been observed in Expt 2 if blood samples had been taken from the sheep at short time intervals after the intraruminal infusions of 'linolenic' or 'linoleic' acids. As yet, it is difficult to put forward any explanation for the highly specific distribution of the polyunsaturated fatty acids between the four lipid fractions in the plasma of the sheep.

It is of interest to note that, in Expt $\mathrm{I}$, the change of diet from hay to dried grass resulted in an increase in the concentration of stearic acid in the plasma triglycerides (Table 2). In Expt 2, the intraruminal infusion of 'linolenic' acid increased the concentration of stearic acid in the plasma triglycerides (Table 4). These findings may be related to the fact that it has been found in experiments in vitro that rumen microorganisms hydrogenate linolenic acid to stearic acid more rapidly than they hydrogenate linoleic acid (J. W. Czerkawski, unpublished observations).

The authors wish to thank Miss I. Fisher, Miss E. Skinner and Mr J. McDill for their skilled technical assistance.

\section{REFERENCES}

Farquhar, J. W., Insull, W., Rosen, P., Stoffel, W. \& Ahrens, E. H. (r959). Nutr. Rev. 17, Suppl. Garton, G. A. \& Duncan, W. R. H. (1964). Biochem. F. 92, 472.

Moore, J. H. \& Williams, D. L. (1963). Can. F. Biochem. Physiol. 41, 1821.

Moore, J. H. \& Williams, D. L. (1964). Biochim biophys. Acta 84, 4 I.

Nelson, G. J. \& Freeman, N. K. (1959). F. biol. Chem. 234, I375.

Noble, R. C. \& Moore, J. H. (1964). Can. F. Biochem. Physiol. 42. 1729.

Senior, J. R. (r964). F. Lipid Res. 5, 495.

Shorland, F. B., Weenink, R. O., Johns, A. T. \& McDonald, I. R. C. (1957). Biochem. F. $67,328$.

Tove, S. B. \& Mochrie, R. D. (1963). F. Dairy Sci. 46, 686. 